\title{
Human Suffering and Natural Experiments: How Empirical Economics can unmask the devastation of Covid-19
}

\author{
Alexandre Olbrecht ${ }^{1}$ \\ Published online: 8 September 2021 \\ (c) EEA 2021
}

In April 2020, the majority of nurses at New York University Medical Center (Tisch Hospital and Langone Health, hereafter NYU) on 1st Avenue at 33rd street would change shifts at $7 \mathrm{pm}$. This was the time when New Yorkers, sequestered in their apartments and homes, would open their windows and cheer for first responders (see Newman, 2020) while radio stations in New York City would play Frank Sinatra's "New York New York." For many nurses, doctors and other health-care professionals at NYU, the shift change was the start of a lonely walk to their hotel rooms in then desolate Manhattan where they would only get a chance to see a glimmer of their families virtually upon arriving in their hotel rooms. Going home after work meant they might bring the new Covid-19 virus to their families and communities, and many health-care workers chose to sacrifice in-person interactions with their closest relatives and to put their and the public's health as a priority.

It was a decision my wife and I made as a family, to live apart during that time, to protect our children and make it safer for them to interact with their grandparents. It put a tremendous amount of stress on our marriage and created heartache for my kids who couldn't spend time with their mother. The topics of conversation during those Facetime calls were difficult and very sad. In one of the conversations, my wife said "they are all dying and we can't help them." It was spoken with heartache, frustration, and fear. It was this fear that was the driving force behind families choosing whenever possible to avoid leaving their homes.

During that time in the United States, three economies quickly emerged. Essential workers (like the doctors and nurses mentioned above) had to report to work, many white-collar workers transitioned to "work-from-home models," and the rest, the majority of which were employed in service industries like restaurants, became unemployed. Every business faced a choice: figure out how to deliver their product in a non-contact or socially distanced way, or close their doors. In economic terms, the methodology of how final goods were distributed in the United States changed

Alexandre Olbrecht

aolbrech@ramapo.edu

1 Anisfield School of Business at Ramapo College of New Jersey and the Executive Director of the Eastern Economic Association, New Jersey, US 
dramatically in a very short time period. As the pandemic continues, some changes will become permanent, while others will eventually return to pre-pandemic status, and in other cases, the pandemic has merely accelerated changes already occurring in the economy.

While the pandemic forced the permanent closure of many businesses, some entrepreneurs created new opportunities. In this issue, Berdiev and Saunoris (2021) find that the pandemic provided a fertile backdrop for new entrepreneurial activity.

In addition to worrying about collapsing economies, governments were forced to also address a public health crisis. The approaches used across the world varied greatly, and Clyde, Kakolyris and Koimisis (2021) evaluate the effectiveness of seven different containment strategies across various OECD countries. Their results reveal that school closings and public transportation closings were the only policies to have lasting impacts; whereas stay-at-home policies only decreased Covid-19 transmission after a 70-day delay.

In the United States, the governmental response to a global pandemic was left up to individual states, with President Donald Trump essentially abdicating any coordinated federal response other than Operation Warp Speed. This meant that all 50 states, headed by individual governors, were forced to make decisions on whether to enact lockdowns, mandate mask requirements, or take other measures, and if so, how strict those measures should be. McCannon (2021) looks at the effects of various policies within the United States by governors and suggests that governors followed the interests of their constituents for the most part.

From the perspective of the economics profession, the pandemic provided a unique opportunity to evaluate the effects of a global pandemic by asking interesting research questions, but the human cost has been staggering. As of July 6, 2021 there have been over 183 million cases globally of Covid-19, with sadly almost 4 million deaths (see WHO website). Bizuneh and Geremew (2021) looked at how Covid19 affected various economies. Much like Buchel, Legge, Pochon and Wegmuller (2020) did for Switzerland, Bizuneh et al (2021) found that Covid-19 decreased GDP growth significantly and the EME countries also faced increased stress in their credit markets.

In the United States, 22.2 million jobs were lost due to the pandemic (see Mutikani, 2021). But those numbers don't measure the true cost of the suffering both here in the United States and across the world. Huato and Chavez (2021) demonstrate that mental health measures deteriorated as a result of Covid-19 among the general population, and thus argue that when the total cost of Covid-19 is calculated, mental health deaths by suicide and other causes as indirect deaths due to this pandemic should be quantified and considered.

In this special issue of the Eastern Economic Journal, we look at how the world has changed due to Covid-19, evaluate the responses from government officials, and try to measure the mental health costs to this pandemic. In addition, we try to understand why the pandemic was worse in some areas as opposed to others. Ang and Murray (2021) looked at how educational attainment, specifically math scores, seemed to be correlated with pandemic outcomes. They found that higher level of mathematical achievement, most likely a proxy variable reflective of overall educational attainment, was associated with lower rates of Covid infection. Medical experts tell us that sadly it 
is likely there will be another global pandemic in our lifetimes, and remind us daily that this one isn't over.

Yet as economists, we tend to focus on the empirical effects of some natural experiment so that we can use statistical analysis to isolate a causality, holding all else constant. But as every reader of this special issue can tell you, Covid-19 has changed their lives, whether it be how they go to work or perhaps sadly the loss of a loved one. This might be the one case in the economics profession when we ask the question, what are the economic effects of Covid-19 and only one data point matters, your own.

While I don't know how this pandemic will end, I do know that the normal ending of an introduction of a special issue of the Eastern Economic Journal should focus on highlighting the articles contained therein, provide context for the readers of the Journal of these articles, and hopefully provide enough academic and intellectual curiosity to motivate additional research in the area of Covid-19 and economics. But this isn't an ordinary issue and so I close with the following: the parade in New York City down the Canyon of Heroes on July 7, 2021, honoring all the medical and essential workers of the city, was a shining example to the thanks and gratitude the world owes all medical and essential workers during this time. Appropriately, like defeating this pandemic, this article begins and ends by mentioning the true heroes of our time.

\section{References}

Ang, J. P., and T. Murray (2021) "Education in Mathematics and the Spread of Covid-19," Eastern Economic Journal. https://doi.org/10.2139/ssrn.3906034.

Berdiev, A., and J. Saunoris (2021) "Do Disease Epidemics Stimulate or Repress Entrepreneurial Activity?," Eastern Economic Journal. https://doi.org/10.1057/s41302-021-00203-w.

Bizuneh, M., and M. Geremew (2021) "Assessing the Impact of Covid-19 Pandemic on Emerging Market Economies' (EMEs) Sovereign Bond Risk Premium and Fiscal Solvency,” Eastern Economic Journal. https://doi.org/10.1057/s41302-021-00201-y.

Buchel, K., Legge, S., Pochon, V., and P. Wegmuller (2020) "Swiss trade during the COVID-19 pandemic: an early appraisal," Swiss Journal of Economics and Statistics. https://doi.org/10.1186/ s41937-020-00069-3.

Clyde, W., Kakolyris, A., and G. Koimisis (2021) "A Study of the Effectiveness of Governmental Strategies for Managing Mortality from Covid-19,' Eastern Economic Journal. https://doi.org/10.1057/ s41302-021-00202-x.

https://covid19.who.int/?gclid=CjwKCAjww-CGBhALEiwAQzWxOqFzp4G8LdCBo48uVkNDwWqqHG 6tM4UcGMqRG1GijJY80kcQxLT-WRoCLgAQAvD_BwE

https://www.reuters.com/article/us-usa-economy/u-s-economy-loses-jobs-as-covid-19-hammers-restaurantsbars-idUSKBN29D0J9

Huato, J., and A. Chavez (2021) "Household Income, Pandemic-Related Income Loss, and the Probability of Anxiety and Depression,” Eastern Economic Journal. https://doi.org/10.1057/s41302-021-00199-3.

McCannon, B. (2021) "Do Governors Lead or Follow? Timing of Stay at Home Orders," Eastern Economic Journal. https://doi.org/10.2139/ssrn.3587452.

Mutikani, L. (2021) "U.S. economy loses jobs as COVID-19 hammers restaurants, bars,"

Newman, A. (2020) "What NYC Sounds Like Every Night at 7". https://www.nytimes.com/interactive/2020/ 04/10/nyregion/nyc-7pm-cheer-thank-you-coronavirus.html

World Health Organization (2021) "WHO Coronavirus (COVID-19) Dashboard,"

Publisher's Note Springer Nature remains neutral with regard to jurisdictional claims in published maps and institutional affiliations. 